\title{
Liquid-liquid phase separation in particles containing secondary organic material free of inorganic salts
}

\author{
Mijung Song ${ }^{1,2}$, Pengfei Liu ${ }^{3}$, Scot T. Martin ${ }^{3,4}$, and Allan K. Bertram ${ }^{2}$ \\ ${ }^{1}$ Department of Earth and Environmental Sciences, Chonbuk National University, Jeollabuk-do, Republic of Korea \\ ${ }^{2}$ Department of Chemistry, University of British Columbia, Vancouver, BC, V6T 1Z1, Canada \\ ${ }^{3}$ John A. Paulson School of Engineering and Applied Sciences, Harvard University, Cambridge, Massachusetts 02138, USA \\ ${ }^{4}$ Department of Earth and Planetary Sciences, Harvard University, Cambridge, Massachusetts 02138, USA
}

Correspondence to: Allan K. Bertram (bertram@chem.ubc.ca)

Received: 2 May 2017 - Discussion started: 11 May 2017

Revised: 8 August 2017 - Accepted: 21 August 2017 - Published: 25 September 2017

\begin{abstract}
Particles containing secondary organic material (SOM) are ubiquitous in the atmosphere and play a role in climate and air quality. Recently, research has shown that liquid-liquid phase separation (LLPS) occurs at high relative humidity (RH) (greater than $\sim 95 \%$ ) in $\alpha$-pinene-derived SOM particles free of inorganic salts, while LLPS does not occur in isoprene-derived SOM particles free of inorganic salts. We expand on these findings by investigating LLPS at $290 \pm 1 \mathrm{~K}$ in SOM particles free of inorganic salts produced from ozonolysis of $\beta$-caryophyllene, ozonolysis of limonene, and photo-oxidation of toluene. LLPS was observed at greater than $\sim 95 \%$ RH in the biogenic SOM particles derived from $\beta$-caryophyllene and limonene while LLPS was not observed in the anthropogenic SOM particles derived from toluene. This work combined with the earlier work on LLPS in SOM particles free of inorganic salts suggests that the occurrence of LLPS in SOM particles free of inorganic salts is related to the oxygen-to-carbon elemental ratio $(\mathrm{O}: \mathrm{C})$ of the organic material. These results help explain the difference between the hygroscopic parameter $\kappa$ of SOM particles measured above and below water saturation in the laboratory and field, and have implications for predicting the cloud condensation nucleation properties of SOM particles.
\end{abstract}

\section{Introduction}

Secondary organic material (SOM) is produced in the atmosphere by the oxidation of volatile organic compounds (VOCs) such as $\alpha$-pinene and isoprene from trees and toluene from anthropogenic sources. Once formed, the low-volatility and semivolatile oxidation products can partition to the particle phase to form SOM-containing particles (Hallquist et al., 2009; Ervens et al., 2011). SOM accounts for approximately $20-80 \%$ of the submicrometer particle mass in the atmosphere (Zhang et al., 2007; Jimenez et al., 2009). Although the exact chemical composition of SOM in atmospheric particles remains an active area of research, laboratory and field studies have shown that the average oxygen-to-carbon elemental ratio $(\mathrm{O}: \mathrm{C})$ of these particles ranges from 0.2 to 1.0 (Chen et al., 2009; Jimenez et al., 2009; Heald et al., 2010; Takahama et al., 2011).

As the relative humidity $(\mathrm{RH})$ varies in the atmosphere, SOM-containing particles can undergo several different phase transitions with implications for the cloud condensation nuclei $(\mathrm{CCN})$ properties, optical properties, reactivity, and growth of these particles (Martin et al., 2000; Raymond and Pandis, 2002; Bilde and Svenningsson, 2004; Zuend et al., 2010; Kuwata and Martin, 2012; Brunamonti et al., 2015). One possible phase transition that SOM particles may undergo as RH varies in the atmosphere is liquidliquid phase separation (LLPS) (Pankow, 2003; Marcolli et al., 2006; Ciobanu et al., 2009: Zuend and Seinfeld, 2012; Veghte et al., 2013; O'Brien et al., 2015). LLPS in particles containing both SOM and inorganic salts has been the focus of many recent studies. These studies have shown that SOM particles mixed with inorganic salts can undergo LLPS in the atmosphere when the $\mathrm{O}: \mathrm{C}$ of the organic material is less than 0.56 , but LLPS may not occur when the $\mathrm{O}: \mathrm{C}$ of the organic material is greater than 0.80 (Bertram et al., 2011; Krieger et 
Table 1. Experimental conditions for production and collection of SOM particles by ozonolysis. Included is the measured separation relative humidity (SRH) upon moistening and mixing relative humidity (MRH) upon drying of the collected particles. Particles were collected on hydrophobic substrates using an electrostatic precipitator or single-stage impactor. The uncertainty in the MRH and SRH values is $\pm 2.0 \%$ $\mathrm{RH}$, due to the uncertainty in the RH measurements.

\begin{tabular}{|c|c|c|c|c|c|c|c|c|}
\hline SOM sample & $\begin{array}{l}\text { VOC } \\
\text { conc. } \\
(\mathrm{ppm})\end{array}$ & $\begin{array}{r}\mathrm{O}_{3} \\
\text { conc. } \\
\text { (ppm) }\end{array}$ & $\begin{array}{r}\text { SOM mass } \\
\text { conc. } \\
\left(\mu \mathrm{g} \mathrm{m}^{-3}\right)^{*}\end{array}$ & $\begin{array}{l}\text { Flow rate for } \\
\text { SOM particle } \\
\text { production } \\
\left(\mathrm{L} \mathrm{min}^{-1}\right)\end{array}$ & $\begin{array}{r}\text { Collection } \\
\text { time } \\
(\mathrm{h})\end{array}$ & $\begin{array}{l}\text { Collection } \\
\text { method }\end{array}$ & $\begin{array}{r}\text { MRH } \\
(\%)\end{array}$ & $\begin{array}{r}\mathrm{SRH} \\
(\%)\end{array}$ \\
\hline$\beta$-Caryophyllene 1 & 0.03 & 30 & $15-30$ & 7.0 & 24 & Single-stage impactor & 92.7 & 94.9 \\
\hline$\beta$-Caryophyllene 2 & 0.03 & 30 & $15-30$ & 7.0 & 46 & Single-stage impactor & 95.0 & 94.4 \\
\hline$\beta$-Caryophyllene 3 & 0.7 & 12 & $2000-4000$ & 3.5 & 6 & Electrostatic precipitator & 90.9 & 91.5 \\
\hline$\beta$-Caryophyllene 4 & 0.7 & 12 & $2000-4000$ & 3.5 & 14 & Electrostatic precipitator & 93.9 & 94.1 \\
\hline$\beta$-Caryophyllene 5 & 0.7 & 12 & $2000-4000$ & 3.5 & 9 & Electrostatic precipitator & 93.9 & 94.1 \\
\hline Limonene 1 & 0.07 & 30 & $80-90$ & 7.0 & 24 & Single-stage impactor & 95.6 & 98.7 \\
\hline Limonene 2 & 0.07 & 30 & $80-90$ & 7.0 & 24 & Single-stage impactor & 97.4 & 98.8 \\
\hline Limonene 3 & 2.0 & 13 & 7000 & 3.5 & 20 & Electrostatic precipitator & 95.6 & 95.3 \\
\hline Limonene 4 & 2.0 & 13 & 7000 & 3.5 & 20 & Electrostatic precipitator & 92.7 & 94.5 \\
\hline
\end{tabular}

* Values derived from number-diameter distribution measured by an SMPS and analyzed using a material density of $1200 \mathrm{~kg} \mathrm{~m}^{-3}$.

al., 2012; Smith et al., 2012; Song et al., 2012a, 2013; Schill and Tolbert, 2013; You et al., 2013, 2014).

Recently, researchers have also focused on LLPS in SOM particles free of inorganic salts. Petters et al. (2006) suggested that a miscibility gap in particles containing organic polymers at high RH may lead to a non-classical pathway for CCN activation. Renbaum-Wolff et al. (2016) showed that $\alpha$-pinene-derived SOM free of inorganic salts can undergo LLPS at high RH values ( $\sim 95$ to $100 \%)$, which could result in altered CCN properties. In addition, they showed that LLPS in SOM particles will lead to a different hygroscopic parameter, $\kappa$, at subsaturated conditions compared to supersaturated conditions. The implication is that the $\mathrm{CCN}$ activity of SOM particles, if they undergo LLPS, is higher than predicted from subsaturated hygroscopicity measurements. Related, Hodas et al. (2016), using a combination of measurements and modeling of surrogates of oligomers, showed that the prevalence of LLPS at high RH can contribute to differences in hygroscopicity above and below water saturation. Most recently, Rastak et al. (2017) observed that isoprenederived SOM particles do not undergo LLPS even at high RH. Rastak et al. (2017) used these results together with thermodynamic calculations to explain the hygroscopic properties of biogenic organic aerosol particles in the laboratory and the field.

Here we expand on the studies by Renbaum-Wolff et al. (2016) and Rastak et al. (2017) by investigated LLPS in SOM particles generated by the ozonolysis of limonene, ozonolysis of $\beta$-caryophyllene, and photo-oxidation of toluene. Limonene and $\beta$-caryophyllene are both biogenic VOCs, while toluene is an anthropogenic VOC (Kanakidou et al., 2005). Both limonene-derived and $\beta$-caryophyllenederived SOM particles have been used as proxies of biogenic SOM particles in the atmosphere (Bateman et al., 2009; Al- farra et al., 2012; Kundu et al., 2012; Frosch et al., 2013; Liu et al., 2013), while toluene-derived SOM has been used as a proxy for anthropogenic SOM particles (Pandis et al., 1992; Robinson et al., 2013; Liu et al., 2016; Song et al., 2016; Ye et al., 2016).

\section{Methods}

\subsection{Production of secondary organic materials}

SOM particles were generated via $\beta$-caryophyllene ozonolysis and limonene ozonolysis in a flow tube reactor and an oxidation flow reactor (OFR) (Table 1), and via toluene photooxidation in the OFR (Table 2). The method of particle generation in the flow tube reactor was described in Shrestha et al. (2013) and the methods of particle generation in the OFR (Kang et al., 2007) were given in Liu et al. (2015). The flow tube reactor was operated at a flow rate of $3.5 \mathrm{~L} \mathrm{~min}^{-1}$ (with a residence time of $38 \mathrm{~s}$ ) and $<5 \% \mathrm{RH}$. The OFR was operated at flow rates of $7.0 \mathrm{~L} \mathrm{~min}^{-1}$ (with a residence time of $110 \mathrm{~s}$ ) and $13 \pm 3 \% \mathrm{RH}$. Both reactors were operated at a temperature of $293 \pm 2 \mathrm{~K}$.

Table 1 lists the experimental conditions for the production of SOM via ozonolysis. For the particle generation via ozonolysis, ozone was produced by irradiating pure air (Aadco 737 Pure Air Generator) with ultraviolet emission from a mercury lamp $(\lambda=185 \mathrm{~nm})$. Ozone concentrations used for ozonolysis ranged from 12 to $30 \mathrm{ppm}$ for $\beta$ caryophyllene and 13 to $30 \mathrm{ppm}$ for limonene (Table 1$). \beta$ Caryophyllene and limonene (Sigma-Aldrich, $\geq 99 \%$ ) were dissolved in 2-butanol (Sigma-Aldrich, $\geq 99.5 \%$ ). These organic solutions were injected into a glass round-bottom flask held at $310 \mathrm{~K}$, where the organic liquids vaporized at the tip 
Table 2. Experimental conditions for production and collection of SOM produced by photo-oxidation. Included are the measured separation relative humidity (SRH) upon moistening and mixing relative humidity (MRH) upon drying of the collected particles. Particles were collected on hydrophobic substrates using an electrostatic precipitator or single-stage impactor. SRH $=0$ and MRH $=0$ indicate LLPS was not observed during humidity cycles.

\begin{tabular}{lrrrrrrrr}
\hline SOM sample & $\begin{array}{r}\text { VOC } \\
\text { conc. } \\
(\mathrm{ppm})\end{array}$ & $\begin{array}{r}\mathrm{O}_{3} \\
\text { conc. } \\
(\mathrm{ppm})\end{array}$ & $\begin{array}{r}\text { SOM mass } \\
\text { conc. } \\
\left(\mu \mathrm{g} \mathrm{m}^{-3}\right)^{*}\end{array}$ & $\begin{array}{r}\text { Flow rate for } \\
\text { SOM particle } \\
\text { production } \\
\left(\mathrm{L} \mathrm{min}^{-1}\right)\end{array}$ & $\begin{array}{r}\text { Collection } \\
\text { time } \\
(\mathrm{h})\end{array}$ & $\begin{array}{r}\text { Collection } \\
\text { method }\end{array}$ & $\begin{array}{r}\text { MRH } \\
(\%)\end{array}$ & $\begin{array}{r}\text { SRH } \\
(\%)\end{array}$ \\
\hline Toluene 2 & 0.2 & 30 & $80-100$ & 7.0 & 24 & Single-stage impactor & 0 & 0 \\
Toluene 3 & 1.0 & 30 & $600-1000$ & 7.0 & 48 & Electrostatic precipitator & 0 & 0 \\
Toluene 4 & 1.0 & 30 & $600-1000$ & 7.0 & 48 & Electrostatic precipitator & 0 & 0 \\
Toluene 5 & 1.0 & 30 & $600-1000$ & 7.0 & 96 & Electrostatic precipitator & 0 & 0 \\
Toluene 6 & 1.0 & 30 & $600-1000$ & 7.0 & 96 & Electrostatic precipitator & 0 & 0 \\
\hline
\end{tabular}

* Values derived from number-diameter distribution measured by an SMPS and analyzed using a material density of $1200 \mathrm{~kg} \mathrm{~m}^{-3}$.

of a syringe. The organic vapor was then swept into the reactor where ozonolysis took place to form SOM and particles. The injected precursor concentrations were $0.03-0.7 \mathrm{ppm}$ for $\beta$-caryophyllene and $0.07-2.0 \mathrm{ppm}$ for limonene in the main flow of the reactor. In the ozonolysis experiments, butanol served as an $\mathrm{OH}$ radical scavenger.

Table 2 presents the experimental conditions for the production of SOM via photo-oxidation. For the particle generation via photo-oxidation, hydroxyl radicals were produced in the OFR by the photochemical reactions:

$\mathrm{O}_{3}+h v \rightarrow \mathrm{O}_{2}+\mathrm{O}\left({ }^{1} \mathrm{D}\right)$,

$\mathrm{O}\left({ }^{1} \mathrm{D}\right)+\mathrm{H}_{2} \mathrm{O} \rightarrow 2 \mathrm{OH}$.

Ozone was again produced by irradiating pure air (Aadco 737 Pure Air Generator) with ultraviolet emission from a mercury lamp $(\lambda=185 \mathrm{~nm})$. Ozone concentrations used in the photo-oxidation studies were $30 \mathrm{ppm}$ (Table 2). Toluene (Sigma-Aldrich, 99\%) was injected and vaporized in a flask, and the vapors were swept into the OFR by purified air. The injected toluene concentrations were $0.2-1.0 \mathrm{ppm}$.

The mass concentration of SOM particles during the generation process was determined from measurements of the number-diameter distribution of SOM particles in the flow tube reactor or OFR and assuming a material density of $1200 \mathrm{~kg} \mathrm{~m}^{-3}$ (Liu et al., 2013). The number-diameter distributions were measured with a scanning mobility particle sizer (SMPS; TSI Inc.). The O : C ratio of the toluene-derived SOM studied here was determined using a high-resolution aerosol mass spectrometer (HR-ToF-AMS; Aerodyne Research Inc.). Data analysis was based on the approach described by Chen et al. (2011).

\subsection{Production of supermicron SOM particles on hydrophobic substrates}

At the outlet of the flow tube reactor and OFR, the submicrometer SOM particles were collected on hydrophobic surfaces. The limonene-derived SOM and toluene-derived SOM particles were collected onto glass slides coated with trichloro $(1 \mathrm{H}, 1 \mathrm{H}, 2 \mathrm{H}, 2 \mathrm{H}$-perfluorooctyl)silane (SigmaAldrich, 97\%). The coating procedure is described in Knopf (2003). The $\beta$-caryophyllene-derived SOM particles were collected onto Teflon substrates.

Two different methods were used to collect submicron particles on hydrophobic substrates (see Tables 1 and 2). The first method used was an electrostatic precipitator (TSI 3089, USA). In this case, the resulting SOM particles on the hydrophobic substrates were smaller than $\sim 10 \mu \mathrm{m}$. From experience in our laboratory, detection of LLPS with our microscope setup is the clearest when the size of the particles are roughly $20-80 \mu \mathrm{m}$. As a result, the following method was used to coagulate the sub- $10 \mu \mathrm{m}$ particles into $20-80 \mu \mathrm{m}$ particles: first the substrate containing the SOM particles was placed in a RH-controlled flow cell (Parsons et al., 2004; Pant et al., 2006; Song et al., 2012b). The RH in the flow cell was then set to over $100 \%$ for $30-60$ min to grow and coagulate the SOM particles. The RH in the flow cell was then decreased to $\sim 80-90 \%$ RH to evaporate the water. During the experiments, the particles were observed using a reflectance microscope (Zeiss Axiotech, 50×). These growth and coagulation processes resulted in SOM particles consisting of 20 $80 \mu \mathrm{m}$ in diameter (Song et al., 2015; Renbaum-Wolff et al., 2016).

In the second method used to collect SOM particles collected on a hydrophobic substrate, a single-stage impactor was used (Prenni et al., 2009; Pöschl et al., 2010; Hosny et al., 2016). In this case, the SOM particles after collection were as big as $100 \mu \mathrm{m}$ due to coagulation during the collection process. Since the particles were already large enough for the LLPS experiments, they were used directly without 


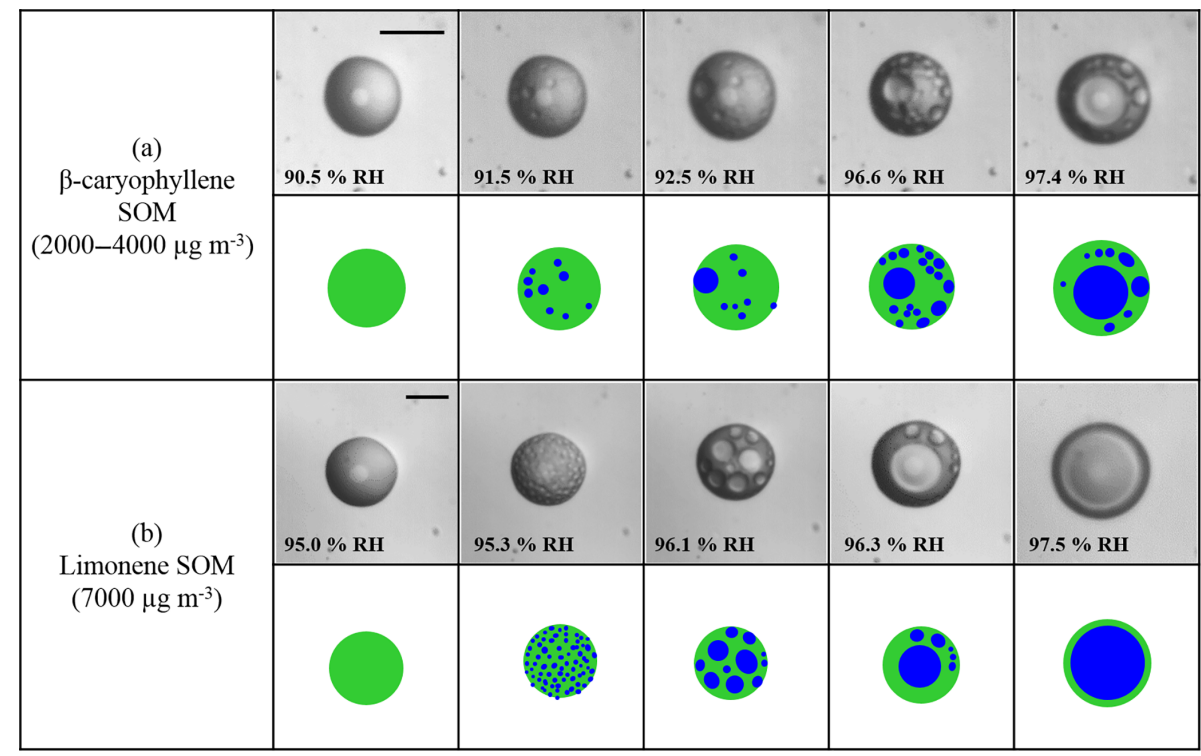

Figure 1. Optical images of SOM particles with increasing RH: (a) $\beta$-caryophyllene-derived SOM for the mass concentrations of 2000$4000 \mu \mathrm{g} \mathrm{m}^{-3}$ ( $\beta$-caryophyllene 3, Table 1) and (b) limonene-derived SOM for the mass concentrations of $7000 \mu \mathrm{g} \mathrm{m} \mathrm{m}^{-3}$ (limonene 3, Table 1). Note that the light gray circles at the center of the particles are an optical effect due to the hemispherical nature of the particles. Illustrations are shown below the images for clarity. Green: SOM-rich phase. Blue: water-rich phase. The scale bar is $20 \mu \mathrm{m}$.

the need for the growth and coagulation experiments described above. Both methods used to collect SOM particles collected both the water-soluble and water-insoluble components of the SOM particles.

\subsection{Optical microscopy of supermicron SOM particles}

For the LLPS experiments, the hydrophobic substrate containing SOM particles with sizes in the range of 20 to $80 \mu \mathrm{m}$ in diameters was mounted in a temperature and $\mathrm{RH}$ controlled flow cell coupled to an optical reflectance microscope (Zeiss Axiotech, 50× objective) (Parsons et al., 2004; Pant et al., 2006; Song et al., 2012b). The temperature of the cell was $290 \pm 1 \mathrm{~K}$ in all experiments. RH in the cell was regulated by varying the ratio of a dry and humidified $\mathrm{N}_{2}$ flow. The total flow rate was $\sim 1200 \mathrm{sccm}$. The RH was determined from measurements of the temperature with a thermocouple and measurements of the dew point/frost point with a chilled mirror sensor (General Eastern, Canada). The RH was calibrated using the deliquescence $\mathrm{RH}$ for pure ammonium sulfate particles $(80 \% \mathrm{RH}$ at $293 \mathrm{~K}$; Martin, 2000). After calibration, the uncertainty of the RH was $\pm 2.0 \%$ based on the reproducibility of multiple deliquesce measurements. At the beginning of LLPS experiments the SOM particles were equilibrated at $\sim 100 \% \mathrm{RH}$ for $15 \mathrm{~min}$. Then the RH was reduced from $\sim 100$ to $\sim 0 \% \mathrm{RH}$ at a rate of 0.1 to $0.5 \% \mathrm{RH} \mathrm{min}{ }^{-1}$, and subsequently increased to $\sim 100 \% \mathrm{RH}$ at a rate of 0.1 to $0.5 \% \mathrm{RH} \mathrm{min}{ }^{-1}$. We did not observe a dependence of LLPS on the RH ramp rate, although only a narrow range of rates were used. During the humidity cycle, optical images of the
SOM particles were recorded every 5-10 s using a CCD camera.

\section{Results and discussion}

\section{1 $\beta$-Caryophyllene-derived and limonene-derived SOM particles}

Humidity cycles at $290 \pm 1 \mathrm{~K}$ were performed for $\beta$ caryophyllene-derived SOM particles generated with mass concentrations of $15-4000 \mathrm{\mu g} \mathrm{m}^{-3}$ and limonenederived SOM generated with mass concentrations of $80-7000 \mu \mathrm{g} \mathrm{m}^{-3}$ (Table 1). In all cases, LLPS was observed at high RH. Table 1 summarizes the results during humidity cycles. Shown in Fig. 1a and Movie S1 (Supplement) are examples of optical images of a $\beta$-caryophyllene-derived SOM particle as a function of increasing $\mathrm{RH}$ for the particle mass concentrations of $2000-4000 \mu \mathrm{g} \mathrm{m}^{-3}$. Shown in Fig. $1 \mathrm{~b}$ and Movie S2 (Supplement) are examples of optical images of a limonene-derived SOM particle as a function of increasing $\mathrm{RH}$ for the particle mass concentrations of $7000 \mu \mathrm{g} \mathrm{m}^{-3}$. For both types of SOM particles, only one phase was observed for RH values from 0 to $\sim 90 \%$. Note the light-colored circle in the center of the particles at $90.5 \%$ $\mathrm{RH}$ for $\beta$-caryophyllene-derived SOM and at $95.0 \% \mathrm{RH}$ for limonene-derived SOM is an optical effect due to the light scattering from a hemispherical particle (Bertram et al., 2011). In Fig. 1, LLPS is observed at $91.5 \%$ RH for the $\beta$-caryophyllene-derived SOM particle and at $95.3 \%$ $\mathrm{RH}$ for the limonene-derived SOM particle. LLPS began 

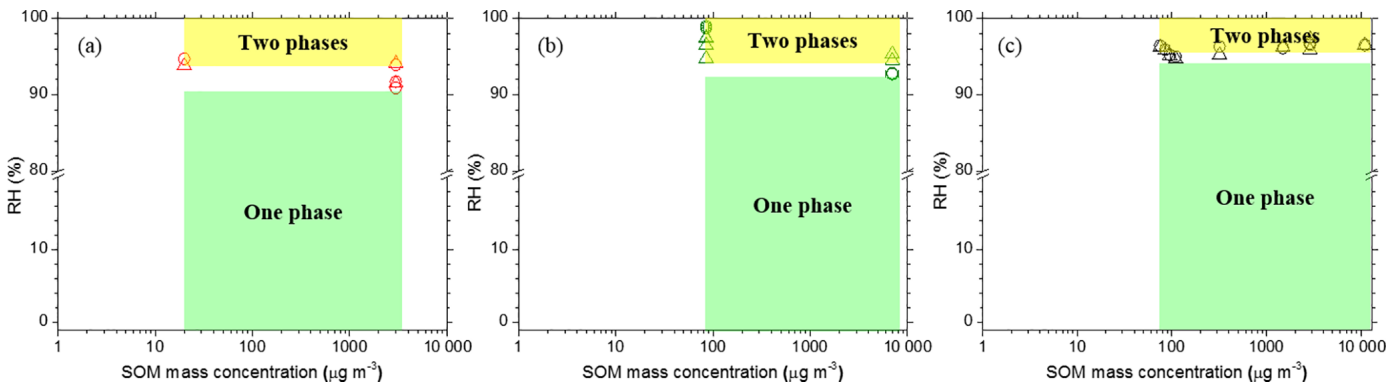

Figure 2. RH at which two phases were observed during humidity cycles of individual particles of (a) $\beta$-caryophyllene-derived SOM and (b) limonene-derived SOM from this study, and (c) $\alpha$-pinene-derived SOM from Renbaum-Wolff et al. (2016) as a function of the SOM mass concentrations. For all panels, circles represent onset of phase separation upon moistening (i.e., separation relative humidity, SRH) and triangles represent mixing of two liquid phases upon drying (i.e., mixing relative humidity, MRH). Yellow shaded region indicates two phases present and green shaded region indicates one phase prevalent in SOM. SOM mass concentrations were derived from measured number-diameter distributions and assuming a material density of $1200 \mathrm{~kg} \mathrm{~m}^{-3}$ (Liu et al., 2013).

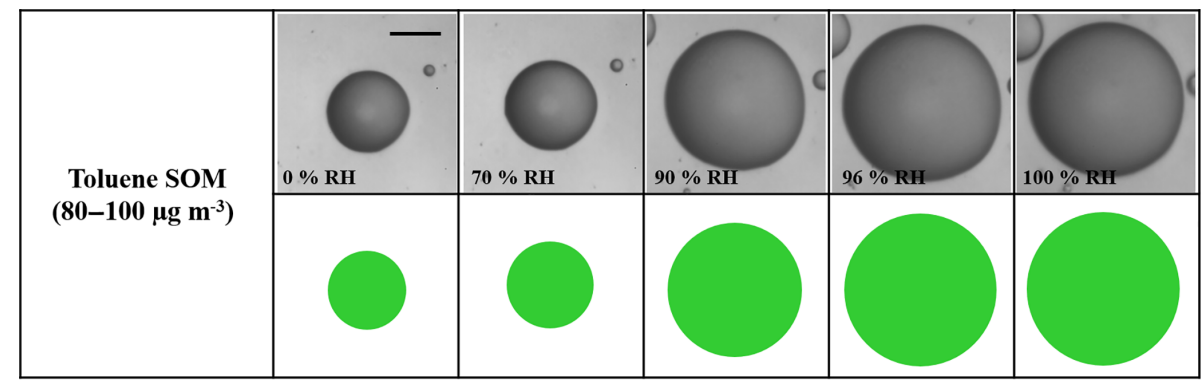

Figure 3. Optical images of toluene-derived SOM for the particle mass concentrations of $80-100 \mu \mathrm{g} \mathrm{m}^{-3}$ (toluene 2, Table 2) with increasing RH. Illustrations of the images are shown for clarity. Green: SOM-rich phase. Size bar is $20 \mu \mathrm{m}$.

with the formation of many small inclusions of a second phase, and in both cases the phase transition occurred over a narrow range of RH. The small inclusions coagulated to larger droplets in the $\beta$-caryophyllene-derived SOM at $92.5 \% \mathrm{RH}$ and in the limonene-derived SOM at $96.1 \% \mathrm{RH}$ (Fig. 1a and b). At the highest RH investigated, a core-shell morphology is observed. Such a core-shell morphology on a hydrophobic substrate has been observed previously by Song et al. (2012b) in particles containing organic, ammonium sulfate and water, although a different morphology can result in the absence of the hydrophobic substrate (Reid et al., 2011). After formation of the core-shell morphology consisting of an inner and outer phase, the two liquid phases co-existed as high as $\sim 100 \% \mathrm{RH}$. We assume that the inner phase is a water-rich phase, while the other phase is an organic-rich phase, since the size of the inner phase decreases as the RH decreases (Renbaum-Wolff et al., 2016). The surface tension of water and the surface tension of more-oxidized and less-oxidized organics is consistent with this assumption (Jasper, 1972). Upon drying, the two liquid phases merge into one liquid phase. This mixing process occurred at $90.9 \% \mathrm{RH}$ for $\beta$-caryophyllene-derived SOM and $95.6 \%$ RH for limonene-derived SOM. Movies of the mixing process are shown in the Supplement (Movies S3 and S4).

Shilling et al. (2009) showed that the O:C of SOM can depend on the particle mass concentration used to generate the SOM. To determine whether the occurrence of LLPS depends on the SOM particle mass concentrations used when generating the SOM, particle mass concentrations ranging from 15 to $7000 \mathrm{\mu g} \mathrm{m}^{-3}$ were investigated (Table 1). Illustrated in Fig. $2 a$ and $b$ is the RH at which two phases were observed during humidity cycles as a function of the mass concentrations of the $\beta$-caryophyllene-derived and limonenederived SOM samples. Triangles represent mixing relative humidity (MRH) of two liquid phases upon drying and circles represents separation relative humidity (SRH) upon moistening.

LLPS was observed at $93.6 \pm 1.5 \% \mathrm{RH}$ in the $\beta$ caryophyllene-derived SOM particles for the particle mass concentrations of $15-4000 \mathrm{~g} \mathrm{~m}^{-3}$ (Fig. 2a). In the limonenederived SOM particles, LLPS occurred at $96.1 \pm 2.1 \% \mathrm{RH}$ for the particle mass concentrations of $80-7000 \mu \mathrm{g} \mathrm{m}^{-3}$ (Fig. 2b). LLPS occurred at $96.0 \pm 0.7 \% \mathrm{RH}$ in $\alpha$-pinenederived SOM particles for the mass concentrations of 75 $11000 \mathrm{\mu g} \mathrm{m}^{-3}$ (Renbaum-Wolff et al., 2016) (Fig. 2c). As shown in Fig. 2, the SRH and MRH of the $\beta$-caryophyllene- 
Table 3. Summary of the LLPS results as well as the average oxygen-to-carbon atomic ratios (O:C) of the studied SOM particles. The standard deviation $(\sigma)$ of the separation relative humidity (SRH) and mixing relative humidity (MRH) is derived from several cycles of RH for different $\mathrm{SOM}$ mass concentrations. $\mathrm{SRH}=0$ and $\mathrm{MRH}=0$ indicate phase separation was not observed. The average $\mathrm{O}: \mathrm{C}$ values for SOM from toluene photo-oxidation are based on the current study (Sect. 2.1). The average O:C values for the other SOM are taken from the literature. Since the average $\mathrm{O}: \mathrm{C}$ can depend on oxidant time and oxidation conditions, we chose literature data that were closest to the experimental conditions used in the LLPS studies (Supplement, Sect. S1 and Table S1).

\begin{tabular}{lllll}
\hline SOM & \multicolumn{2}{c}{ Average O : } & \multicolumn{2}{c}{ Average RH $(\%) \pm \sigma$} \\
\cline { 2 - 5 } & Lowest & Highest & MRH & SRH \\
\hline Ozonolysis of $\beta$-caryophyllene & $0.36^{\mathrm{a}}$ & $0.38^{\mathrm{a}}$ & $93.3 \pm 1.7$ & $93.8 \pm 1.3$ \\
Ozonolysis of $\alpha$-pinene & $0.42^{\mathrm{a}}$ & $0.44^{\mathrm{a}}$ & $95.9 \pm 0.8^{\mathrm{b}}$ & $96.1 \pm 0.6^{\mathrm{b}}$ \\
Ozonolysis of limonene & $0.34^{\mathrm{c}}$ & $0.40^{\mathrm{c}}$ & $95.3 \pm 1.9$ & $96.8 \pm 2.2$ \\
Photo-oxidation of isoprene & $0.52^{\mathrm{d}}$ & $0.89^{\mathrm{a}}$ & $0^{\mathrm{e}}$ & $0^{\mathrm{e}}$ \\
Photo-oxidation of toluene & $1.14^{\mathrm{f}}$ & $1.30^{\mathrm{f}}$ & 0 & 0 \\
\hline
\end{tabular}

${ }^{\mathrm{a}} \mathrm{Li}$ et al. (2015); ${ }^{\mathrm{b}}$ Renbaum-Wolff et al. (2016); ${ }^{\mathrm{c}}$ Heaton et al. (2007); ${ }^{\mathrm{d}}$ Lambe et al. (2015); ${ }^{\mathrm{e}}$ Rastak et al. (2017); ${ }^{\mathrm{f}}$ this study.

Table 4. Literature data of measured average $\mathrm{O}: \mathrm{C}, \kappa_{\mathrm{HGF}}, \kappa_{\mathrm{CCN}}$, and the difference between $\kappa_{\mathrm{HGF}}$ and $\kappa_{\mathrm{CCN}}$, denoted as $\Delta \kappa$, of SOMs. The average $\mathrm{O}: \mathrm{C}$ values are based on measurements from the individual studies referenced here. The experimental conditions for the studies reported in Table 4 were not necessarily similar to the experimental conditions for the studies reported in Table 3, even if the same precursor volatile organic compound was used.

\begin{tabular}{lrrrrl}
\hline SOM & O : C & $\begin{array}{r}\kappa_{\mathrm{HGF}} \text { at } \\
90 \% \mathrm{RH}\end{array}$ & $\kappa_{\mathrm{CCN}}$ & $\Delta \kappa$ & Reference \\
\hline Photo-oxidation of & 0.4 & 0.04 & 0.15 & 0.11 & Massoli et al. (2010) \\
$\alpha$-pinene & 0.43 & 0.07 & 0.16 & 0.09 & Massoli et al. (2010) \\
& 0.45 & 0.03 & 0.11 & 0.08 & Pajunoja et al. (2015) \\
& 0.55 & 0.10 & 0.12 & 0.02 & Pajunoja et al. (2015) \\
& 0.67 & 0.14 & 0.18 & 0.04 & Massoli et al. (2010) \\
& 0.70 & 0.12 & 0.13 & 0.01 & Pajunoja et al. (2015) \\
\hline Photo-oxidation of & 0.86 & 0.13 & 0.14 & 0.01 & Pajunoja et al. (2015) \\
isoprene & & & & & \\
\hline Photo-oxidation of & 0.39 & 0.02 & 0.10 & 0.08 & Pajunoja et al. (2015) \\
longifolene & 0.56 & 0.03 & 0.09 & 0.06 & Pajunoja et al. (2015) \\
& 0.83 & 0.08 & 0.10 & 0.02 & Pajunoja et al. (2015) \\
\hline
\end{tabular}

derived SOM, limonene-derived SOM, and $\alpha$-pinene-derived SOM particles do not depend strongly on the SOM particle mass concentrations used to generate the SOM.

\subsection{Toluene-derived SOM}

Humidity cycles were also performed for SOM particles generated from photo-oxidation of toluene using particle mass concentrations of $80-1000 \mu \mathrm{g} \mathrm{m}^{-3}$ in the reactor (Table 2). None of the toluene-derived SOM particles underwent LLPS during RH cycling even at high RH (Table 2).

Shown in Fig. 3 and Movie S5 (Supplement) are optical images of a toluene-derived SOM particle for mass concentrations of $80-100 \mu \mathrm{g} \mathrm{m}^{-3}$. Images in Fig. 3 and Movie S5 were recorded as the RH was increased. No LLPS was observed in the SOM particle during RH cycling between 0 and $100 \%$. Rastak et al. (2017) did not observe LLPS in isoprene-derived SOM particles for the mass concentrations of $60-1000 \mu \mathrm{g} \mathrm{m}^{-3}$

\subsection{Relation between LLPS and $\mathrm{O}$ : $\mathrm{C}$}

Summarized in Table 3 are the average SRH and MRH values determined in our work and by Renbaum-Wolff et al. (2016) and Rastak et al. (2017). The average SRH and MRH values are based on several cycles of RH for different SOM mass concentrations. Also included in Table 3 are the average $\mathrm{O}: \mathrm{C}$ values for the studied SOM particles. The average $\mathrm{O}: \mathrm{C}$ values for SOM from toluene photo-oxidation are based on the current study (Sect. 2.1). The average O:C values for the other SOM are taken from the literature. Since the average $\mathrm{O}: \mathrm{C}$ can depend on oxidant time and oxidation conditions, we chose literature data that were closest to the experimental 


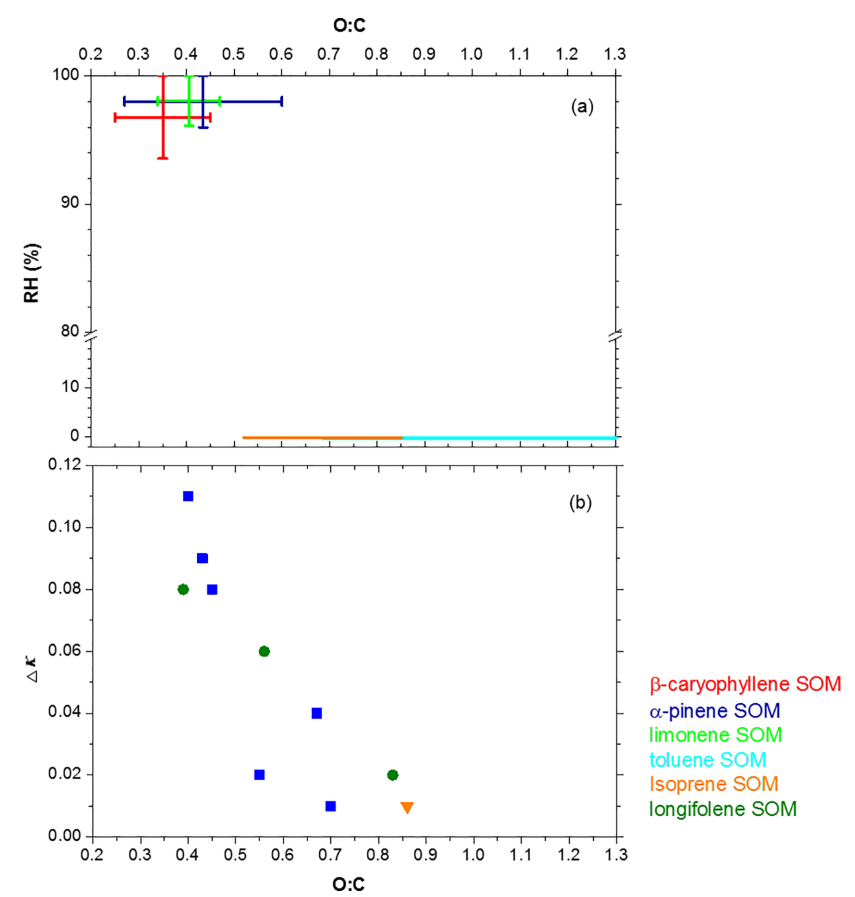

Figure 4. (a) Separation relative humidity (SRH) as a function of the average $\mathrm{O}: \mathrm{C}$ of the organic material. Shown are the results from Table 3. $\beta$-Caryophyllene-derived SOM (red), limonene-derived SOM (light green), and toluene-derived SOM (cyan) from this study, isoprene-derived SOM (orange) from Rastak et al. (2017) and $\alpha$-pinene-derived SOM (blue) from Renbaum-Wolff et al. (2016) as a function of $\mathrm{O}: \mathrm{C}$. RH value of $0 \%$ indicates that LLPS did not occur. The $\mathrm{O}: \mathrm{C}$ values of the SOM particles were taken from Table 3. (b) The difference between $\kappa_{\mathrm{HGF}}$ and $\kappa_{\mathrm{CCN}}$, denoted as $\Delta \kappa$, as a function of the average O : C of the SOM. Data taken from Table 4. The experimental conditions for the studies reported in (a) were not necessarily similar to the experimental conditions for the studies reported in (b), even if the same precursor volatile organic compound was used.

conditions used when studying LLPS (Supplement, Sect. S1 and Table S1).

Based on the data shown in Table 3, there appears to be a relationship between the occurrence of LLPS and the average $\mathrm{O}: \mathrm{C}$ of the organic material: when the average $\mathrm{O}: \mathrm{C}$ was between 0.34 and 0.44 , LLPS was observed, but when the average $\mathrm{O}: \mathrm{C}$ was between 0.52 and 1.30, LLPS was not observed. This trend is also apparent in Fig. 4a, where SRH data in Table 3 are plotted versus the $\mathrm{O}: \mathrm{C}$ data in Table 3 .

SOM have an average $\mathrm{O}: \mathrm{C}$ and a spread (or distribution) of O : C values. Similar to SOM, systems containing two organics and water also have a spread in $\mathrm{O}: \mathrm{C}$ and an average $\mathrm{O}: \mathrm{C}$. Hence, as a starting point to understanding LLPS in SOM, we considered previous studies that explored the miscibility gap in bulk solutions containing two organics and water (see Table 1 in Ganbavale et al., 2015). When the average $\mathrm{O}: \mathrm{C}$ of the organic material was low in a system containing two organic components with water, LLPS was observed.
For example, LLPS was observed in a mixture of 1-butanol $(\mathrm{O}: \mathrm{C}=0.25)$, 1-propanol $(\mathrm{O}: \mathrm{C}=0.20)$, and water (GomisYagües et al., 1998) and in a mixture of 1-pentanol $(\mathrm{O}: \mathrm{C}=$ 0.20 ), acetone ( $\mathrm{O}: \mathrm{C}=0.33$ ), and water (Tiryaki et al., 1994). On the other hand, when the average $\mathrm{O}: \mathrm{C}$ of the organic material was high in a system containing two organics and water, LLPS was not observed. For example, LLPS was not observed in a mixture of acetic acid $(\mathrm{O}: \mathrm{C}=1.00)$, ethanol $(\mathrm{O}: \mathrm{C}=0.50)$, and water (Pickering, 1893). We conclude that the relationship between average $\mathrm{O}: \mathrm{C}$ and LLPS in SOM observed here is not inconsistent with previous LLPS studies in systems containing two organics and water. In addition to the average $\mathrm{O}: \mathrm{C}$, the spread in $\mathrm{O}: \mathrm{C}$ in organic mixtures will also be important for LLPS (Renbaum-Wolff et al., 2016).

\section{Implications}

As mentioned in the introduction, Petters et al. (2006), Hodas et al. (2016), Renbaum-Wolff et al. (2016), and Rastak et al. (2017) showed using thermodynamic calculations that SOM particles that undergo LLPS at high RH values have modified CCN properties. Hence, LLPS should be considered when predicting the $\mathrm{CCN}$ properties of SOM particles derived from $\alpha$-pinene ozonolysis, $\beta$-caryophyllene ozonolysis, and limonene ozonolysis. A caveat is that the mass concentrations used when generating the SOM particles in our experiments was larger than normally found in the atmosphere (Zhang et al., 2007; Jimenez et al., 2009; Spracklen et al., 2011; Li et al., 2015). Additional studies are needed to confirm LLPS in SOM particles generated using more atmospherically relevant SOM mass concentrations.

Discrepancy between the hygroscopic parameter, $\kappa$ (Petters and Kreidenweis, 2007), measured below water saturation $\left(\kappa_{\mathrm{HGF}}\right)$ and above water saturation $\left(\kappa_{\mathrm{CCN}}\right)$ in $\mathrm{SOM}$ particles have been reported in several studies (Petters et al., 2006, 2009; Prenni et al., 2007; Juranyi et al., 2009; Good et al., 2010; Irwin et al., 2010, 2011 Massoli et al., 2010; Dusek et al., 2011; Hersey et al., 2013; Pajunoja et al., 2015; Zhao et al., 2016). Petters et al. (2006), Hodas et al. (2016), Renbaum-Wolff et al. (2016) and Rastak et al. (2017) suggested that such discrepancies are expected in systems that undergo LLPS at high RH. Summarized in Table 4 and Fig. $4 \mathrm{~b}$ are literature data on the difference between $\kappa_{\mathrm{HGF}}$ and $\kappa_{\mathrm{CCN}}$ (denoted $\Delta \kappa$ ) as a function of average $\mathrm{O}: \mathrm{C}$ of the organic material studied (Prenni et al., 2007; Massoli et al., 2010; Pajunoja et al., 2015). The experimental conditions (oxidation time and oxidation level) for the studies reported in Table 4 were not necessarily similar to the experimental conditions for the studies reported in Table 3, even if the same precursor volatile organic compound was used.

Figure $4 \mathrm{~b}$ suggests that $\Delta \kappa$ is related to the average $\mathrm{O}: \mathrm{C}$ of the organic material. Figure $4 \mathrm{a}$ and $\mathrm{b}$ combined suggests that when the average $\mathrm{O}: \mathrm{C}$ is small, LLPS occurs and the difference between $\kappa_{\mathrm{HGF}}$ and $\kappa_{\mathrm{CCN}}$ is large. On the other 
hand, when the average $\mathrm{O}: \mathrm{C}$ is large, LLPS does not occur and the difference between $\kappa_{\mathrm{HGF}}$ and $\kappa_{\mathrm{CCN}}$ is small. Figure 4 provides additional support for the suggestion that the LLPS is related to the discrepancies between $\kappa_{\mathrm{HGF}}$ and $\kappa_{\mathrm{CCN}}$.

Data availability. Underlying material and related items for this paper are located in the Supplement.

\section{The Supplement related to this article is available online at https://doi.org/10.5194/acp-17-11261-2017- supplement.}

Competing interests. The authors declare that they have no conflict of interest.

Acknowledgements. This work was supported by the Natural Sciences and Engineering Research Council of Canada. Support from the US National Science Foundation (AGS-1640378) and the US Department of Energy (DE-SC0012792) is also acknowledged. Mijung Song acknowledges support from a National Research Foundation of Korea (NRF) grant funded by the Korean government (MSIP) (2016R1C1B1009243).

Edited by: David Topping

Reviewed by: two anonymous referees

\section{References}

Alfarra, M. R., Hamilton, J. F., Wyche, K. P., Good, N., Ward, M. W., Carr, T., Barley, M. H., Monks, P. S., Jenkin, M. E., Lewis, A. C., and McFiggans, G. B.: The effect of photochemical ageing and initial precursor concentration on the composition and hygroscopic properties of $\beta$-caryophyllene secondary organic aerosol, Atmos. Chem. Phys., 12, 6417-6436, https://doi.org/10.5194/acp-12-6417-2012, 2012.

Bateman, A. P., Nizkorodov, S. A., Laskin, J., and Laskin, A.: Time-resolved molecular characterization of limonene/ozone aerosol using high-resolution electrospray ionization mass spectrometry, Phys. Chem. Chem. Phys., 11, 7931-7942, https://doi.org/10.1039/b905288g, 2009.

Bertram, A. K., Martin, S. T., Hanna, S. J., Smith, M. L., Bodsworth, A., Chen, Q., Kuwata, M., Liu, A., You, Y., and Zorn, S. R.: Predicting the relative humidities of liquid-liquid phase separation, efflorescence, and deliquescence of mixed particles of ammonium sulfate, organic material, and water using the organic-to-sulfate mass ratio of the particle and the oxygen-tocarbon elemental ratio of the organic component, Atmos. Chem. Phys., 11, 10995-11006, https://doi.org/10.5194/acp-11-109952011, 2011.

Bilde, M. and Svenningsson, B.: CCN activation of slightly soluble organics: the importance of small amounts of inorganic salt and particle phase, Tellus B, 56, 128-134, https://doi.org/10.1111/j.1600-0889.2004.00090.x, 2004.
Brunamonti, S., Krieger, U. K., Marcolli, C., and Peter, T.: Redistribution of black carbon in aerosol particles undergoing liquidliquid phase separation, Geophys. Res. Lett., 42, 2532-2539, https://doi.org/10.1002/2014g1062908, 2015.

Chen, Q., Farmer, D. K., Schneider, J., Zorn, S. R., Heald, C. L., Karl, T. G., Guenther, A., Allan, J. D., Robinson, N., Coe, H., Kimmel, J. R., Pauliquevis, T., Borrmann, S., Pöschl, U., Andreae, M. O., Artaxo, P., Jimenez, J. L., and Martin, S. T.: Mass spectral characterization of submicron biogenic organic particles in the Amazon Basin, Geophys. Res. Lett., 36, L20806, https://doi.org/10.1029/2009g1039880, 2009.

Chen, Q., Liu, Y. J., Donahue, N. M., Shilling, J. E., and Martin, S. T.: Particle-Phase Chemistry of Secondary Organic Material: Modeled Compared to Measured O:C and H:C Elemental Ratios Provide Constraints, Environ. Sci. Technol., 45, 4763-4770, https://doi.org/10.1021/es104398s, 2011.

Ciobanu, V. G., Marcolli, C., Krieger, U. K., Weers, U., and Peter, T.: Liquid-Liquid Phase Separation in Mixed Organic/Inorganic Aerosol Particles, J. Phys. Chem. A., 113, 10966-10978, https://doi.org/10.1021/Jp905054d, 2009.

Dusek, U., Frank, G. P., Massling, A., Zeromskiene, K., Iinuma, Y., Schmid, O., Helas, G., Hennig, T., Wiedensohler, A., and Andreae, M. O.: Water uptake by biomass burning aerosol at suband supersaturated conditions: closure studies and implications for the role of organics, Atmos. Chem. Phys., 11, 9519-9532, https://doi.org/10.5194/acp-11-9519-2011, 2011.

Ervens, B., Turpin, B. J., and Weber, R. J.: Secondary organic aerosol formation in cloud droplets and aqueous particles (aqSOA): a review of laboratory, field and model studies, Atmos. Chem. Phys., 11, 11069-11102, https://doi.org/10.5194/acp-1111069-2011, 2011.

Frosch, M., Bilde, M., Nenes, A., Praplan, A. P., Juranyi, Z., Dommen, J., Gysel, M., Weingartner, E., and Baltensperger, U.: CCN activity and volatility of beta-caryophyllene secondary organic aerosol, Atmos. Chem. Phys., 13, 2283-2297, 10.5194/acp-132283-2013, 2013.

Ganbavale, G., Zuend, A., Marcolli, C., and Peter, T.: Improved AIOMFAC model parameterisation of the temperature dependence of activity coefficients for aqueous organic mixtures, Atmos. Chem. Phys., 15, 447-493, https://doi.org/10.5194/acp-15447-2015, 2015.

Gomis-Yagues, V., Ruiz-Bevia, F., Ramos-Nofuentes, M., and Fernandez-Torres, M. J.: The influence of the temperature on the liquid-liquid equilibrium of the ternary system 1butanol-1-propanol-water, Fluid Phase Equilibr., 149, 139-145, https://doi.org/10.1016/S0378-3812(98)00315-X, 1998.

Good, N., Topping, D. O., Duplissy, J., Gysel, M., Meyer, N. K., Metzger, A., Turner, S. F., Baltensperger, U., Ristovski, Z., Weingartner, E., Coe, H., and McFiggans, G.: Widening the gap between measurement and modelling of secondary organic aerosol properties?, Atmos. Chem. Phys., 10, 2577-2593, https://doi.org/10.5194/acp-10-2577-2010, 2010.

Hallquist, M., Wenger, J. C., Baltensperger, U., Rudich, Y., Simpson, D., Claeys, M., Dommen, J., Donahue, N. M., George, C., Goldstein, A. H., Hamilton, J. F., Herrmann, H., Hoffmann, T., Iinuma, Y., Jang, M., Jenkin, M. E., Jimenez, J. L., Kiendler-Scharr, A., Maenhaut, W., McFiggans, G., Mentel, Th. F., Monod, A., Prévôt, A. S. H., Seinfeld, J. H., Surratt, J. D., Szmigielski, R., and Wildt, J.: The formation, properties and im- 
pact of secondary organic aerosol: current and emerging issues, Atmos. Chem. Phys., 9, 5155-5236, https://doi.org/10.5194/acp9-5155-2009, 2009.

Heald, C. L., Kroll, J. H., Jimenez, J. L., Docherty, K. S., DeCarlo, P. F., Aiken, A. C., Chen, Q., Martin, S. T., Farmer, D. K., and Artaxo, P.: A simplified description of the evolution of organic aerosol composition in the atmosphere, Geophys. Res. Lett., 37, L08803, https://doi.org/10.1029/2010g1042737, 2010.

Heaton, K. J., Dreyfus, M. A., Wang, S., and Johnston, M. V.: Oligomers in the early stage of biogenic secondary organic aerosol formation and growth, Environ. Sci. Technol., 41, 6129_ 6136, https://doi.org/10.1021/es070314n, 2007.

Hersey, S. P., Craven, J. S., Metcalf, A. R., Lin, J., Lathem, T., Suski, K. J., Cahill, J. F., Duong, H. T., Sorooshian, A., Jonsson, H. H., Shiraiwa, M., Zuend, A., Nenes, A., Prather, K. A., Flagan, R. C., and Seinfeld, J. H.: Composition and hygroscopicity of the Los Angeles Aerosol: CalNex, J. Geophys. Res.-Atmos., 118, 30163036, https://doi.org/10.1002/jgrd.50307, 2013.

Hodas, N., Zuend, A., Schilling, K., Berkemeier, T., Shiraiwa, M., Flagan, R. C., and Seinfeld, J. H.: Discontinuities in hygroscopic growth below and above water saturation for laboratory surrogates of oligomers in organic atmospheric aerosols, Atmos. Chem. Phys., 16, 12767-12792, https://doi.org/10.5194/acp-1612767-2016, 2016

Hosny, N. A., Fitzgerald, C., Vysniauskas, A., Athanasiadis, A., Berkemeier, T., Uygur, N., Pöschl, U., Shiraiwa, M., Kalberer, M., Pope, F. D., and Kuimova, M. K.: Direct imaging of changes in aerosol particle viscosity upon hydration and chemical aging, Chem. Sci., 7, 1357-1367, https://doi.org/10.1039/c5sc02959g, 2016.

Irwin, M., Good, N., Crosier, J., Choularton, T. W., and McFiggans, G.: Reconciliation of measurements of hygroscopic growth and critical supersaturation of aerosol particles in central Germany, Atmos. Chem. Phys., 10, 11737-11752, https://doi.org/10.5194/acp-10-11737-2010, 2010.

Irwin, M., Robinson, N., Allan, J. D., Coe, H., and McFiggans, G.: Size-resolved aerosol water uptake and cloud condensation nuclei measurements as measured above a Southeast Asian rainforest during OP3, Atmos. Chem. Phys., 11, 11157-11174, https://doi.org/10.5194/acp-11-11157-2011, 2011.

Jasper, J. J.: The surface tension of pure liquid compounds, J. Phys. And Chem. Ref. Data, Vol 1, 841-1009, https://doi.org/10.1063/1.3253106, 1972.

Jimenez, J. L., Canagaratna, M. R., Donahue, N. M., Prevot, A. S. H., Zhang, Q., Kroll, J. H., DeCarlo, P. F., Allan, J. D., Coe, H., Ng, N. L., Aiken, A. C., Docherty, K. S., Ulbrich, I. M., Grieshop, A. P., Robinson, A. L., Duplissy, J., Smith, J. D., Wilson, K. R., Lanz, V. A., Hueglin, C., Sun, Y. L., Tian, J., Laaksonen, A., Raatikainen, T., Rautiainen, J., Vaattovaara, P., Ehn, M., Kulmala, M., Tomlinson, J. M., Collins, D. R., Cubison, M. J., Dunlea, E. J., Huffman, J. A., Onasch, T. B., Alfarra, M. R., Williams, P. I., Bower, K., Kondo, Y., Schneider, J., Drewnick, F., Borrmann, S., Weimer, S., Demerjian, K., Salcedo, D., Cottrell, L., Griffin, R., Takami, A., Miyoshi, T., Hatakeyama, S., Shimono, A., Sun, J. Y., Zhang, Y. M., Dzepina, K., Kimmel, J. R., Sueper, D., Jayne, J. T., Herndon, S. C., Trimborn, A. M., Williams, L. R., Wood, E. C., Middlebrook, A. M., Kolb, C. E., Baltensperger, U., and Worsnop, D. R.: Evolution of Or- ganic Aerosols in the Atmosphere, Science, 326, 1525-1529, https://doi.org/10.1126/science.1180353, 2009.

Juranyi, Z., Gysel, M., Duplissy, J., Weingartner, E., Tritscher, T., Dommen, J., Henning, S., Ziese, M., Kiselev, A., Stratmann, F., George, I., and Baltensperger, U.: Influence of gas-to-particle partitioning on the hygroscopic and droplet activation behaviour of alpha-pinene secondary organic aerosol, Phys. Chem. Chem. Phys., 11, 8091-8097, https://doi.org/10.1039/B904162a, 2009.

Kanakidou, M., Seinfeld, J. H., Pandis, S. N., Barnes, I., Dentener, F. J., Facchini, M. C., Van Dingenen, R., Ervens, B., Nenes, A., Nielsen, C. J., Swietlicki, E., Putaud, J. P., Balkanski, Y., Fuzzi, S., Horth, J., Moortgat, G. K., Winterhalter, R., Myhre, C. E. L., Tsigaridis, K., Vignati, E., Stephanou, E. G., and Wilson, J.: Organic aerosol and global climate modelling: a review, Atmos. Chem. Phys., 5, 1053-1123, https://doi.org/10.5194/acp-5-10532005, 2005.

Kang, E., Root, M. J., Toohey, D. W., and Brune, W. H.: Introducing the concept of Potential Aerosol Mass (PAM), Atmos. Chem. Phys., 7, 5727-5744, https://doi.org/10.5194/acp-7-5727-2007, 2007.

Knopf, D. A.: Thermodynamic properties and nucleation processes of upper tropospheric and lower stratospheric aerosol particles, Diss. ETH No. 15103, Zurich, Switzerland, 2003.

Krieger, U. K., Marcolli, C., and Reid, J. P.: Exploring the complexity of aerosol particle properties and processes using single particle techniques, Chem. Soc. Rev., 41, 6631-6662, https://doi.org/10.1039/c2cs35082c, 2012.

Kundu, S., Fisseha, R., Putman, A. L., Rahn, T. A., and Mazzoleni, L. R.: High molecular weight SOA formation during limonene ozonolysis: insights from ultrahigh-resolution FT-ICR mass spectrometry characterization, Atmos. Chem. Phys., 12, 5523-5536, https://doi.org/10.5194/acp-12-5523-2012, 2012.

Kuwata, M. and Martin, S. T.: Phase of atmospheric secondary organic material affects its reactivity, P. Natl. Acad. Sci. USA, 109, 17354-17359, https://doi.org/10.1073/pnas.1209071109, 2012.

Lambe, A. T., Chhabra, P. S., Onasch, T. B., Brune, W. H., Hunter, J. F., Kroll, J. H., Cummings, M. J., Brogan, J. F., Parmar, Y., Worsnop, D. R., Kolb, C. E., and Davidovits, P.: Effect of oxidant concentration, exposure time, and seed particles on secondary organic aerosol chemical composition and yield, Atmos. Chem. Phys., 15, 3063-3075, https://doi.org/10.5194/acp15-3063-2015, 2015.

Li, Y. J., Liu, P. F., Gong, Z. H., Wang, Y., Bateman, A. P., Bergoend, C., Bertram, A. K., and Martin, S. T.: Chemical Reactivity and Liquid/Nonliquid States of Secondary Organic Material, Environ. Sci. Technol., 49, 13264-13274, https://doi.org/10.1021/acs.est.5b03392, 2015.

Liu, P. F., Abdelmalki, N., Hung, H.-M., Wang, Y., Brune, W. H., and Martin, S. T.: Ultraviolet and visible complex refractive indices of secondary organic material produced by photooxidation of the aromatic compounds toluene and $m$-xylene, Atmos. Chem. Phys., 15, 1435-1446, https://doi.org/10.5194/acp15-1435-2015, 2015.

Liu, P. F., Li, Y. J., Wang, Y., Gilles, M. K., Zaveri, R. A., Bertram, A. K., and Martin, S. T.: Lability of secondary organic particulate matter, P. Natl. Acad. Sci. USA, 113, 12643-12648, https://doi.org/10.1073/pnas.1603138113, 2016.

Liu, P. F., Zhang, Y., and Martin, S. T.: Complex Refractive Indices of Thin Films of Secondary Organic Materials by Spectroscopic 
Ellipsometry from 220 to $1200 \mathrm{~nm}$, Environ. Sci. Technol., 47, 13594-13601, https://doi.org/10.1021/Es403411e, 2013.

Marcolli, C. and Krieger, U. K.: Phase changes during hygroscopic cycles of mixed organic/inorganic model systems of tropospheric aerosols, J. Phys. Chem. A., 110, 1881-1893, https://doi.org/10.1021/Jp0556759, 2006.

Martin, S. T.: Phase transitions of aqueous atmospheric particles, Chem. Rev., 100, 3403-3453, https://doi.org/10.1021/Cr990034t, 2000.

Massoli, P., Lambe, A. T., Ahern, A. T., Williams, L. R., Ehn, M., Mikkila, J., Canagaratna, M. R., Brune, W. H., Onasch, T. B., Jayne, J. T., Petaja, T., Kulmala, M., Laaksonen, A., Kolb, C. E., Davidovits, P., and Worsnop, D. R.: Relationship between aerosol oxidation level and hygroscopic properties of laboratory generated secondary organic aerosol (SOA) particles, Geophys. Res. Lett., 37, L2480110, https://doi.org/10.1029/2010g1045258, 2010.

O'Brien, R. E., Wang, B. B., Kelly, S. T., Lundt, N., You, Y., Bertram, A. K., Leone, S. R., Laskin, A., and Gilles, M. K.: Liquid-liquid phase separation in aerosol particles: Imaging at the nanometer scale, Environ. Sci. Technol., 49, 4995-5002, https://doi.org/10.1021/acs.est.5b00062, 2015.

Pajunoja, A., Lambe, A. T., Hakala, J., Rastak, N., Cummings, M. J., Brogan, J. F., Hao, L. Q., Paramonov, M., Hong, J., Prisle, N. L., Malila, J., Romakkaniemi, S., Lehtinen, K. E. J., Laaksonen, A., Kulmala, M., Massoli, P., Onasch, T. B., Donahue, N. M., Riipinen, I., Davidovits, P., Worsnop, D. R., Petaja, T., and Virtanen, A.: Adsorptive uptake of water by semisolid secondary organic aerosols, Geophys. Res. Lett., 42, 3063-3068, https://doi.org/10.1002/2015gl063142, 2015.

Pandis, S. N., Harley, R. A., Cass, G. R., and Seinfeld, J. H.: Secondary organic aerosol formation and transport, Atmos. Environ. a-Gen, 26, 2269-2282, https://doi.org/10.1016/09601686(92)90358-R, 1992.

Pankow, J. F.: Gas/particle partitioning of neutral and ionizing compounds to single and multi-phase aerosol particles. 1. Unified modeling framework, Atmos. Environ., 37, 3323-3333, https://doi.org/10.1016/S1352-2310(03)00346-7, 2003.

Pant, A., Parsons, M. T., and Bertram, A. K.: Crystallization of aqueous ammonium sulfate particles internally mixed with soot and kaolinite: Crystallization relative humidities and nucleation rates, J. Phys. Chem. A., 110, 8701-8709, https://doi.org/10.1021/Jp060985s, 2006.

Parsons, M. T., Mak, J., Lipetz, S. R., and Bertram, A. K.: Deliquescence of malonic, succinic, glutaric, and adipic acid particles, J. Geophys. Res.-Atmos., 109, D06212, https://doi.org/10.1029/2003jd004075, 2004.

Petters, M. D., Kreidenweis, S. M., Snider, J. R., Koehler, K. A., Wang, Q., Prenni, A. J., and Demott, P. J.: Cloud droplet activation of polymerized organic aerosol, Tellus B, 58, 196-205, https://doi.org/10.1111/j.1600-0889.2006.00181.x, 2006.

Petters, M. D. and Kreidenweis, S. M.: A single parameter representation of hygroscopic growth and cloud condensation nucleus activity, Atmos. Chem. Phys., 7, 1961-1971, https://doi.org/10.5194/acp-7-1961-2007, 2007.

Petters, M. D., Wex, H., Carrico, C. M., Hallbauer, E., Massling, A., McMeeking, G. R., Poulain, L., Wu, Z., Kreidenweis, S. M., and Stratmann, F.: Towards closing the gap between hygroscopic growth and activation for secondary organic aerosol - Part
2: Theoretical approaches, Atmos. Chem. Phys., 9, 3999-4009, https://doi.org/10.5194/acp-9-3999-2009, 2009.

Pickering, S.: LXXI, A study of the properties of some strong solutions, J. Chem. Soc., 63, 998-1027, 1893.

Pöschl, U., Martin, S. T., Sinha, B., Chen, Q., Gunthe, S. S., Huffman, J. A., Borrmann, S., Farmer, D. K., Garland, R. M., Helas, G., Jimenez, J. L., King, S. M., Manzi, A., Mikhailov, E., Pauliquevis, T., Petters, M. D., Prenni, A. J., Roldin, P., Rose, D., Schneider, J., Su, H., Zorn, S. R., Artaxo, P., and Andreae, M. O.: Rainforest aerosols as biogenic nuclei of clouds and precipitation in the Amazon, Science, 329, 1513-1516, https://doi.org/10.1126/science.1191056, 2010.

Prenni, A. J., Petters, M. D., Kreidenweis, S. M., DeMott, P. J., and Ziemann, P. J.: Cloud droplet activation of secondary organic aerosol, J. Geophys. Res.-Atmos., 112, D10223, https://doi.org/10.1029/2006jd007963, 2007.

Prenni, A. J., Petters, M. D., Kreidenweis, S. M., Heald, C. L., Martin, S. T., Artaxo, P., Garland, R. M., Wollny, A. G., and Pöschl, U.: Relative roles of biogenic emissions and Saharan dust as ice nuclei in the Amazon basin, Nat. Geosci., 2, 401-404, https://doi.org/10.1038/Ngeo517, 2009.

Rastak, N., Pajunoja, A., Navarro, J. C. A., Ma, J., Song, M., Partridge, D. G., Kirkevag, A., Leong, Y., Hu, W. W., Taylor, N. F., Lambe, A., Cerully, K., Bougiatioti, A., Liu, P., Krejci, R., Petaja, T., Percival, C., Davidovits, P., Worsnop, D. R., Ekman, A. M. L., Nenes, A., Martin, S., Jimenez, J. L., Collins, D. R., Topping, D. O., Bertram, A. K., Zuend, A., Virtanen, A., and Riipinen, I.: Microphysical explanation of the RH-dependent water affinity of biogenic organic aerosol and its importance for climate, Geophys. Res. Lett., 44, 5167-5177, https://doi.org/10.1002/2017gl073056, 2017.

Raymond, T. M. and Pandis, S. N.: Cloud activation of singlecomponent organic aerosol particles, J. Geophys. Res.-Atmos., 107, 478710, https://doi.org/10.1029/2002jd002159, 2002.

Reid, J. P., Dennis-Smither, B. J., Kwamena, N. O. A., Miles, R. E. H., Hanford, K. L., and Homer, C. J.: The morphology of aerosol particles consisting of hydrophobic and hydrophilic phases: hydrocarbons, alcohols and fatty acids as the hydrophobic component, Phys. Chem. Chem. Phys., 13, 15559-15572, https://doi.org/10.1039/C1cp21510h, 2011.

Reinhardt, A., Emmenegger, C., Gerrits, B., Panse, C., Dommen, J., Baltensperger, U., Zenobi, R., and Kalberer, M.: Ultrahigh mass resolution and accurate mass measurements as a tool to characterize oligomers in secondary organic aerosols, Anal. Chem., 79, 4074-4082, https://doi.org/10.1021/ac062425v, 2007.

Renbaum-Wolff, L., Song, M., Marcolli, C., Zhang, Y., Liu, P. F., Grayson, J. W., Geiger, F. M., Martin, S. T., and Bertram, A. K.: Observations and implications of liquid-liquid phase separation at high relative humidities in secondary organic material produced by $\alpha$-pinene ozonolysis without inorganic salts, Atmos. Chem. Phys., 16, 7969-7979, https://doi.org/10.5194/acp16-7969-2016, 2016.

Robinson, E. S., Saleh, R., and Donahue, N. M.: Organic aerosol mixing observed by single-particle mass spectrometry, J. Phys. Chem. A., 117, 13935-13945, https://doi.org/10.1021/jp405789t, 2013.

Schill, G. P. and Tolbert, M. A.: Heterogeneous ice nucleation on phase-separated organic-sulfate particles: effect of liquid 
vs. glassy coatings, Atmos. Chem. Phys., 13, 4681-4695, https://doi.org/10.5194/acp-13-4681-2013, 2013.

Shilling, J. E., Chen, Q., King, S. M., Rosenoern, T., Kroll, J. H., Worsnop, D. R., DeCarlo, P. F., Aiken, A. C., Sueper, D., Jimenez, J. L., and Martin, S. T.: Loading-dependent elemental composition of $\alpha$-pinene SOA particles, Atmos. Chem. Phys., 9, 771-782, https://doi.org/10.5194/acp-9-771-2009, 2009.

Shrestha, M., Zhang, Y., Ebben, C. J., Martin, S. T., and Geiger, F. M.: Vibrational sum frequency generation spectroscopy of secondary organic material produced by condensational growth from alpha-pinene ozonolysis, J. Phys. Chem. A., 117, 84278436, https://doi.org/10.1021/Jp405065d, 2013.

Smith, M. L., Bertram, A. K., and Martin, S. T.: Deliquescence, efflorescence, and phase miscibility of mixed particles of ammonium sulfate and isoprene-derived secondary organic material, Atmos. Chem. Phys., 12, 9613-9628, https://doi.org/10.5194/acp-12-9613-2012, 2012.

Song, M., Marcolli, C., Krieger, U. K., Zuend, A., and Peter, T.: Liquid-liquid phase separation in aerosol particles: Dependence on $\mathrm{O}: \mathrm{C}$, organic functionalities, and compositional complexity, Geophys. Res. Lett., 39, L19801, https://doi.org/10.1029/2012g1052807, 2012a.

Song, M., Marcolli, C., Krieger, U. K., Zuend, A., and Peter, T.: Liquid-liquid phase separation and morphology of internally mixed dicarboxylic acids/ammonium sulfate/water particles, Atmos. Chem. Phys., 12, 2691-2712, https://doi.org/10.5194/acp12-2691-2012, 2012b.

Song, M. J., Marcolli, C., Krieger, U. K., Lienhard, D. M., and Peter, T.: Morphologies of mixed organic/inorganic/aqueous aerosol droplets, Faraday Discuss., 165, 289-316, https://doi.org/10.1039/C3fd00049d, 2013.

Song, M., Liu, P. F., Hanna, S. J., Li, Y. J., Martin, S. T., and Bertram, A. K.: Relative humidity-dependent viscosities of isoprene-derived secondary organic material and atmospheric implications for isoprene-dominant forests, Atmos. Chem. Phys., 15, 5145-5159, https://doi.org/10.5194/acp-155145-2015, 2015.

Spracklen, D. V., Jimenez, J. L., Carslaw, K. S., Worsnop, D. R., Evans, M. J., Mann, G. W., Zhang, Q., Canagaratna, M. R., Allan, J., Coe, H., McFiggans, G., Rap, A., and Forster, P.: Aerosol mass spectrometer constraint on the global secondary organic aerosol budget, Atmos. Chem. Phys., 11, 12109-12136, https://doi.org/10.5194/acp-11-12109-2011, 2011.

Takahama, S., Schwartz, R. E., Russell, L. M., Macdonald, A. M., Sharma, S., and Leaitch, W. R.: Organic functional groups in aerosol particles from burning and non-burning forest emissions at a high-elevation mountain site, Atmos. Chem. Phys., 11, 6367-6386, https://doi.org/10.5194/acp-11-6367-2011, 2011.

Tiryaki, A., Guruz, G., and Orbey, H.: Liquid-Liquid Equilibria of Ternary-Systems of Water Plus Acetone and C-5-Alcohol and C8-Alcohol at 298-K, 303-K and 308-K, Fluid Phase Equilibr., 94, 267-280, https://doi.org/10.1016/0378-3812(94)87061-6, 1994.
Veghte, D. P., Altaf, M. B., and Freedman, M. A.: Size Dependence of the Structure of Organic Aerosol, J. Am. Chem. Soc., 135, 16046-16049, https://doi.org/10.1021/ja408903g, 2013.

Ye, Q., Robinson, E. S., Ding, X., Ye, P. L., Sullivan, R. C., and Donahue, N. M.: Mixing of secondary organic aerosols versus relative humidity, P. Natl. Acad. Sci. USA, 113, 12649-12654, https://doi.org/10.1073/pnas.1604536113, 2016.

You, Y., Renbaum-Wolff, L., and Bertram, A. K.: Liquid-liquid phase separation in particles containing organics mixed with ammonium sulfate, ammonium bisulfate, ammonium nitrate or sodium chloride, Atmos. Chem. Phys., 13, 11723-11734, https://doi.org/10.5194/acp-13-11723-2013, 2013.

You, Y., Smith, M. L., Song, M. J., Martin, S. T., and Bertram, A. K.: Liquid-liquid phase separation in atmospherically relevant particles consisting of organic species and inorganic salts, Int. Rev. Phys. Chem., 33, 43-77, https://doi.org/10.1080/0144235X.2014.890786, 2014.

Zhang, Q., Jimenez, J. L., Canagaratna, M. R., Allan, J. D., Coe, H., Ulbrich, I., Alfarra, M. R., Takami, A., Middlebrook, A. M., Sun, Y. L., Dzepina, K., Dunlea, E., Docherty, K., DeCarlo, P. F., Salcedo, D., Onasch, T., Jayne, J. T., Miyoshi, T., Shimono, A., Hatakeyama, S., Takegawa, N., Kondo, Y., Schneider, J., Drewnick, F., Borrmann, S., Weimer, S., Demerjian, K., Williams, P., Bower, K., Bahreini, R., Cottrell, L., Griffin, R. J., Rautiainen, J., Sun, J. Y., Zhang, Y. M., and Worsnop, D. R.: Ubiquity and dominance of oxygenated species in organic aerosols in anthropogenically-influenced Northern Hemisphere midlatitudes, Geophys. Res. Lett., 34, L13801, https://doi.org/10.1029/2007gl029979, 2007.

Zhao, D. F., Buchholz, A., Kortner, B., Schlag, P., Rubach, F., Fuchs, H., Kiendler-Scharr, A., Tillmann, R., Wahner, A., Watne, A. K., Hallquist, M., Flores, J. M., Rudich, Y., Kristensen, K., Hansen, A. M. K., Glasius, M., Kourtchev, I., Kalberer, M., and Mentel, Th. F.: Cloud condensation nuclei activity, droplet growth kinetics, and hygroscopicity of biogenic and anthropogenic secondary organic aerosol (SOA), Atmos. Chem. Phys., 16, 1105-1121, https://doi.org/10.5194/acp16-1105-2016, 2016.

Zuend, A., Marcolli, C., Peter, T., and Seinfeld, J. H.: Computation of liquid-liquid equilibria and phase stabilities: implications for RH-dependent gas/particle partitioning of organicinorganic aerosols, Atmos. Chem. Phys., 10, 7795-7820, https://doi.org/10.5194/acp-10-7795-2010, 2010.

Zuend, A. and Seinfeld, J. H.: Modeling the gas-particle partitioning of secondary organic aerosol: the importance of liquidliquid phase separation, Atmos. Chem. Phys., 12, 3857-3882, https://doi.org/10.5194/acp-12-3857-2012, 2012. 